\title{
THE DARK LORD OF THE DARK ROOM
}

\section{DR SHRADDHA ASHAPURE}

Assistant Professor in English, Name of university -Govt College, DAVV, Indore.

Indore-452001 Madhya Pradesh

\begin{abstract}
R.K. Narayan is a veteran of literary craft. We are honoured to have such an Indian writer whose literary masterpieces have chiselled out many innovative paradigms and characters that are iconic to the hypnotised readers. These fictitious characters have been related to many real-life scenarios.

Narayan's Savitri accepts to abandon her home, husband and her kids once she comes to know of her husband's cuckoldry. Narayan efficiently displays her dilemmas and diligence in his sarcastic elusive manner. Savitri is just a common, affable homemaker. She forsakes her gambler and unloving spouse and her family.

My attention has been caught by such cynic character Ramani who is the Hitler in The Dark Room of Narayan. He is a sort of shady aristocrat of the dark room which he creates for his wife as well as his entire family. He possesses all the attributes of being a dark lord he is a tyrant, dominant self-centred self-fish and disloyal towards his devoted wife Savitri he insults and rebukes her for no reason but to satisfy his worthless patriarchal urges, this dark lord is disbursed by scepticism and is very governing in his attitude. He forced his dutiful wife to live in his dark room of his self-interest and arrogance Owing to his petulant and insolent brashness, a frightful hard luck and despondency always lurks in his house. He is like a bully in his demeanour with his spouse Savitri and kids. His rejoinder to her is bereft of any temperateness and fondness. Ramani is a thankless husband and affectionless father. Even after spending 15 years together under the same roof with his wife, he treats her lesser than a maid in this case a maid without pay of 24x7. He frequently rebukes his children even on insignificant stuff. His self-obsession hindered him to express his love for his own family.
\end{abstract}

KEYWORDS: Paradox, Infidelity, Attributes, Rebukes, Scepticism \& Self-Obsession

Received: May 26, 2021; Accepted: Jun 16, 2021; Published: Jun 30, 2021; Paper Id: IJELDEC20213

\section{INTRODUCTION}

This is another research paper on my most favourite writer Dr RK Narayan who has been the domain of my doctorate studies as well, here I have chosen the novel The Dark Room (1938) this novel is based on the marital relationship which is as dark and bitter as the title itself suggests. The Dark Room (1938) is all about a loveless marriage. Ramani is employed as the office secretary in an Insurance Company in Malgudi. His temperament is cynical. Instead of being a loving compassionate head of the family, he rules his house according to his own sweet will. As he is always emotionally unavailable to his wife, Savitri and his children, they are always terrified as they never know his erratic and eccentric manners.

At this point, I am reminded of Narayan's another novel which is also my favourite one The English teacher, the plot of this novel is also based on the nuptial bond of husband-and-wife Krishna and Sushila but the treatment of marriage in both the novels are completely different In English teacher we find the unconditional love of spouse that crosses the barriers of separate realms even whereas in The dark room spouses are poles apart in their 
outlook which is based on the code of ruler and subjects. That is why while reading both the novels tears welled up in my eyes being a female myself I could relate and relive the agony of Savitri and Sushil although my sympathies and empathies build-up for both the female characters, emotions that brought out my tears were completely for different reasons, in the English teacher I cried out at the loyalty and unfailing faith of the husband Krishna towards his wife Sushila I was speechless for the concern and care of a dying mother for her 3 years old daughter Leela and devoted husband I was envious for Shushila as she was so fortunate to have such a devoted and loyal spouse. I too basked in the hope and joy of the close-knitted family of theirs but The dark room novel made me scared and disappointed knowing that Savitri was abandoned by her husband and she was left all alone with her agonies.

In this novel The Dark Room Novel, RK Narayan scrutinizes the gender discriminations of traditional Indian society in the pre-independence era. He voices the social injustice and discrimination against women. In The Dark Room, he does this through the lens of domestic vehemence and cacophony of a disturbed family. It presents an ugly picture of a disturbed household overwhelmed with domestic skirmish. We find in this novel his remarkable signature style of straightforwardness and elusive hilarity. He narrates stories of Ramani and his household trying to live their simple lives in a changing world. The Dark Room (1938) presents the struggle of a defenceless woman, Savitri. She has got nothing from her husband Ramani apart from reprimands and manipulations. He treats the children in a similar way. She then becomes a rebel and abandons the house in anguish to commit self-destruction. She is saved and this becomes the turning point of her life she takes the decision to live a self-regulating life but realizes the vainness of her effort to escape from her ties with the world and comes back home.

Undoubtedly The Dark Room presents conjugal discontent and domestic bitterness and Narayan sets down a portion of life as he truly witnesses. However, the storyline is so obvious, the underlying theme is intensely representative and universal in its treatment, any lady sharing similar woes of Savitri will identify with her. The central theme in the novel is the treachery and thanklessness of Ramani who was always emotionally absent from his family. The female protagonist is left imprisoned in an existential mess of unreciprocated ethical struggle close to life and death.

Ramani is self-declared god of his family. His rules of discipline in his family for his wife and children cross the limit of fatherly love and changes into cruel conditions. He converts his home into a sort of military base where his words become the law.

Initially, the soft side of Ramani is shown to us by Narayan, where he is possessive for Savitri and wants to enjoy Tamil movies with her all alone like a newlywed couple without the hassle of children. He never cares to even know the feelings of his wife or kids. Ramani is in a way so self-obsessed that he never shares his own feelings with his family and keep them hidden from all. I guess he is afraid to show his vulnerability to all which according to him might be taken as his weakness that his family may use to dominate him therefore, he maintains an image of a very strict father and expressionless husband.

Although being a female I can navigate effortlessly through the psychic of Savitri as well as the vamp of this novel that is Shanta Bai. Both are contradictory to each other in their traits and treatment, if Savitri is a symbol of suppressed, submissive surrendering soul on the other hand Shanta Bai is an arrogant, candid and brazen woman who manipulates lustful 
man like Ramani to meet her selfish needs. I wonder who becomes the victim and who is the predator whether it is Ramani who preys upon the depend on poor Savitri or it is sensual Shanta who pounce upon the unmet sensual needs of Ramani? Whatever may be the case but the question to ponder upon is; what were the reasons that made an unknown lady ruins the foundation of their fifteen years old marriage? I believe the bottom line is lack of trust and love that is the biggest threat to any relationship, be it of blood ties or any two people sharing marital bonds, if there is a true bond of unconditional love and faith between two people or couple no one can dare to break it. Ramani is a man of a double standard, he has a dual personality he wants a docile wife cum maid to run his house impeccably and at the same time, he desires a mistress who can satisfy his erotic wishes. After reading this novel several times I comprehended that actually, it was never the mistake of Savitri to be at par with the terms of Ramani she did her best in every role assigned to her by Ramani, be it wife or mother or housekeeper. The problem lies with this never contented Ramani. At times I find him craving and longing for the things, for those emotions, he never wants really. I guess even if Savitri gave him her life he the fault finder would start a new blame game.

Concubines like Shanta Bai are present in every era and every society they are a kind of valve used by the menfolk for centuries to release their pent up false emotions and play game on their falsified egos. I don't agree that she is the epitome of empowered woman, Does empowerment means robbing someone of their spouse and ruining the peace and wellbeing of an entire family? She uses her charms cunningly to seduce a man who is already so lusty and of weak character. Her dramatic demonstration of exaggerated moves made him deeply infatuated and he compares it with his wife's unpolished grumbling in the dark room. Ramani is responsible for bringing out Shantabai certain insincerities of the female inner self to the surface. Shanta Bai seems to be entirely contradictory to Savitri. Like Savitri, Shanta Bai has grilled the epitomes of society, adjudicated her husband and found him deficient and abandoned him. But contrasting with Savitri, Shanta Bai does not return to her house. She was incapable to limit herself to her house where her husband and children live.

According to Shanta Bai, her survival and her monetary liberation weigh more than her matrimonial relationship. Poni is another robust and resolute female character in this novel whose shocking thoughts comes to the surface via her brashness towards male dominated society she treats men like her slaves.

When near the culmination of the novel, Savitri resolves to homecoming. Poni advises her to maintain her dignity and not to give up before the narcissism of her spouse,

Savitri is impressed by the audacity of this female and agrees to it in her heart, but she knows that she would not be able to muster enough courage to implement Poni's advice into the act. Ramani is of worse nature as compared to Poni's husband. His presence itself is so fearful for the family members that they can't breathe properly and feel suffocated. On top of that, his loose character makes the matter worse. A wife can tolerate all kinds of cruelties and insincerities of her spouse but infidelity is unforgivable and beyond tolerance, when Ramani is obsessed by Shanta Bai who joins his company as the first female probationer. Savitri pretends unawareness firstly, but her patience and tolerance cross the limit when Ramani fails to turn up one night, she decides to attack back. Her husband's duplicity and disloyalty compel her to shed her image of a timid wife. Only challenging times determine the amount of courage we each possess same happened with our Savitri from meekness to deserting her home, this terrible, next to impossible, the move is made by her only on this provocation of 
her husband and now she comprehends how reliant on she is upon her husband. A timid Savitri turns against the legendary insinuation of her name, objecting to being taken for granted. She now realises that due to his petulant and insolent arrogance, there is always a sense of awful disaster and desolation pervasive in his house. He is like a dictator in his conduct with his wife Savitri, daughters and servants.

This story is amazingly relevant in the present scenario as it was way back when it was first printed in 1938, it definitely provides a thought stimulating read. It echoes the biased dictatorship of a male-controlled society. Skilfully intertwined around flat characters, and intermingled with welcoming gusts of humour 'The Dark Room' truthfully defines the distinctive genuineness of that time's conventional Chennai household. Written in a modest, eloquent language, a fiction so moving and hitherto so factual, could have only been written by RK Narayan.

Discontent couples like Ramani and Savitri can be found in Indian society at any time. The Dark Room is about an overriding, unreasonably critical and selfish husband, Ramani living with his wife Savitri and three children. The readers become familiar with his personality map as we see him as a faultfinder, criticising everything that his wife serves him on the table. He expletives the cook and scoffs at his wife till his heart's content. At his office, he is more than a little extravagant to a junior called Shanta Bai. She is attractive and freshly parted from her husband. Ramani is taken in by her charming mannerism and goes out of his way to help her out, that includes evacuating an extra room in the office and even compelling his wife to give away some of their furniture to make Shanta comfortable. On the way from his golf club, he frequently starts spending quality time with her and sits engrossed listening to her.

When Savitri hears of it she is unable to tolerate the humiliation. Her patience fails her tolerance. Dismayed at being taken so entirely for granted she advances her voice and then is determined to leave the house. Her helplessness makes me so emotional she has no right over her own kids as Ramani did not permit her to take along with her own children.

This bold step of stepping out from the threshold of her house instils in her newfound courage and confidence. She decides to discover her new identity now.

Ramani represents the ego of Indian male who considers himself to be superior to female. Narayan created the characters which are representative. In this stirring tale, R. K. Narayan again takes us back to Mysore and into the captivating creation of his invented locale, Malgudi, where we are familiarised with Savitri and Ramani. Narayan paints his literary craft with the colours of quiet irony and subtle humour which have become so distinctive and identification mark of him. Events reach a peak point when Savitri's much-loved piece of furniture, a bench, is hired by Ramani to equip the room he has speedily accumulated for Shanta Bai in the office. Savitri withdraws into herself and lies quite still in the one secluded place she has of her own, the dark room. After more infidelity of her spouse, Savitri packs up the very few things she has and leaves the house, leaving her children staring in vacuum. Savitri tries to drown herself but is saved. For a short time, she struggles to be self-reliant but understands quite soon that she must return although: part of her has died. Narayan's concerned treatment of his characters makes this a most rewarding and poignant book to read. In The Dark Room, Narayan is able to portray the bitterness of an unsatisfied relationship. He effectively depicts Ramani as a futile, ironic, egotistic man. This novel makes you relate yourself with Ramani in his egoistic ways and with Savitri in her docile ways as it gives a delightful emotional vision into human character and pulse with a usual astonishment so exclusive to R K Narayan's works. 
Amazingly any Indian wife can relate herself to Savitri who is as ordinary, sociable, obedient and submissive as our Savitri is. In fact, I consider Ramani as the lucky one to get such a partner who kept all the seven vows, she had taken at the time of their marriage despite the fact that Ramani had broken most of the vows.

\section{REFERENCES}

1. Biswall Jayant K. A Critical Study of the Novels of R. K. Narayan: The Malgudi Comedy, New Delhi: Nirmal Publishers and Distributers, 1987.

2. Naik MK. A History of Indian English Literature. New Delhi: Sahitya Akademy, 2010.

3. Nure Jannat \& Md. Tapu Rayhan, “Tree Without Roots: An Archaic of Majeed as an Extremist and a Colonialist”, International Journal of English and Literature (IJEL), Vol. 8, Issue 5,pp, 43-52

4. Sharan Nagendra Nath. A Critical Study of the Novels of R. K. Narayan. New Delhi: Classical Publishing Company, 1993.

5. Hariprasanna A. The World of Malgudi: A Study of R. K. Narayan Novels. New Delhi: Prestige Books, 199.

6. Nariman Larbi, “The Constructedness of Englishness in Julian Barnes's Arthur \& George ",International Journal of English and Literature (IJEL) ,Vol. 7, Issue 2,pp, 117-126

7. Narayan RK. My Days (autobiography) Mysore Indian Thoughts Publications, 1971.

8. Kalim Siddiqui, "Higher Education in the Era of Globalisation"International Journal of Humanities and Social Sciences (IJHSS),Vol. 3, Issue 2,pp, 9-32

9. Naik MK. A History of Indian English Literature. New Delhi: Sahitya Academy, 2010.

10. Holmstrom Lakshmi, 'Women as Makers of Social Change: The Dark Room, The Guide and The Painter of Signs', in R.K. Narayan An Anthology of Recent Criticism, C.N.

11. Srinath (ed), (New Orientation Series, Pencraft Internationa, New Delhi, 2000)

12. M. M. Sulphey, “The Utility of Q-methodology in Human Resource Management Research”,International Journal of Human Resources Management (IJHRM) ,Vol. 3, Issue 3, Nov 2014, 15-26

13. Margaret Berry, "R.K. Narayan: Lila and Literature", The Journal of Indian Writing in English, Vol.4, No.2.

14. Harish Raizada, "Point of View in the Novels of R.K. Narayan", Perspectives on R.K. Narayan, ed. Atma Ram (Ghaziabad: Vimal Prakashan, 1981).

15. K.R. Srinivasa Iyengar, Indian Writing in English (New Delhi: Sterling Publishing Private Limited, 2001). Delhi: Atlantic Publishers and Distributors, 2010.

16. Kierkegaard, Soren. Sickness Unto Death. London: Harpur, 1898.

17. Krishnaswamy, Shanta. The Woman In Indian Fiction 1950-1980. New Delhi: Ashish Publishing House, 2001.

18. .Narayan, R.K. The Dark Room. Chennai: Indian Thought Publication, 1938.

19. .Sartre, Jean-Paul. Being and Nothingness, trans. Hazel Barnes. 
New York: Washington Square Press. 1992.

20. Walsh, William. R. K. Narayan: A Critical Appreciation. New

Delhi: Allied Publishers Private Ltd, 1942. 